Prepared in cooperation with the U.S. Environmental Protection Agency, Region V

\title{
Flood-Inundation Maps for a 15-Mile Reach of the Kalamazoo River from Marshall to Battle Creek, Michigan
}

Pamphlet to accompany

Scientific Investigations Map 3135 



\section{Flood-Inundation Maps for a 15-Mile Reach of the Kalamazoo River from Marshall to Battle Creek, Michigan}

By Christopher J. Hoard, Kathleen K. Fowler, Moon H. Kim, Chad D. Menke, Scott E. Morlock, Marie C. Peppler, Cynthia M. Rachol, and Matthew T. Whitehead

Prepared in cooperation with the U.S. Environmental Protection Agency, Region V

Pamphlet to accompany

Scientific Investigations Map 3135 


\title{
U.S. Department of the Interior \\ KEN SALAZAR, Secretary \\ U.S. Geological Survey \\ Marcia K. McNutt, Director
}

\section{U.S. Geological Survey, Reston, Virginia: 2010}

\author{
For more information on the USGS — the Federal source for science about the Earth, its natural and living resources, \\ natural hazards, and the environment, visit http://www.usgs.gov or call 1-888-ASK-USGS \\ For an overview of USGS information products, including maps, imagery, and publications, \\ visit http://www.usgs.gov/pubprod \\ To order this and other USGS information products, visit http://store.usgs.gov
}

Any use of trade, product, or firm names is for descriptive purposes only and does not imply endorsement by the U.S. Government.

Although this report is in the public domain, permission must be secured from the individual copyright owners to reproduce any copyrighted materials contained within this report.

Suggested citation:

Hoard, C.J., Fowler, K.K., Kim, M.H., Menke, C.D., Morlock, S.E., Peppler, M.C., Rachol, C.M., and Whitehead, M.T., 2010, Flood-inundation maps for a 15-mile reach of the Kalamazoo River from Marshall to Battle Creek, Michigan:

U.S. Geological Survey Scientific Investigations Map 3135, 6 p. pamphlet, 6 sheets, scale 1:100,000. 


\section{Contents}

Abstract
Introduction
Purpose and Scope
Study Area Description
Antecedent Conditions
Calculating Flood Probabilities
Inundation Mapping
Summary
Acknowledgments

\section{Figures}

1. Location of the Kalamazoo River and Enbridge oil-spill response divisions .....................2

2. Illustration showing NEXRAD 1-day observed precipitation storm tracks from July 22 to July 25, 2010; NEXRAD data from National Weather Service data center located in Grand Rapids, Michigan...

3. Discharge hydrographs for the Kalamazoo River near Marshall, Kalamazoo River near Battle Creek, and Battle Creek River at Battle Creek streamgages

\section{Tables}

1. Precipitation, in inches, measured at Enviro-Weather Automated Weather Network stations, July 22-25, 2010.

2. Gage height, water-surface altitude, and discharge associated with the July 25,2010 , and the $0.2,1,2,4$, and 10 percent flood exceedance events for the Kalamazoo River at Marshall (station 4103500) 


\section{Sheets}

1. Flood-Inundation map of the Kalamazoo River from Marshall to Battle Creek Michigan, for the July 25, 2010, flood corresponding to a gage height of 7.44 feet and an altitude of 884.09 feet (NAVD88) at the U.S. Geological Survey streamgage at Marshall, Michigan (station ID 04103500).

2. Flood-Inundation map of the Kalamazoo River from Marshall to Battle Creek Michigan, for a flood with a 10-percent exceedance probability corresponding to a gage height of 7.10 feet and an altitude of 883.75 feet (NAVD88) at the U.S. Geological Survey streamgage at Marshall, Michigan (station ID 04103500).

3. Flood-Inundation map of the Kalamazoo River from Marshall to Battle Creek Michigan, for a flood with a 4-percent exceedance probability corresponding to a gage height of 7.60 feet and an altitude of 884.25 feet (NAVD88) at the U.S. Geological Survey streamgage at Marshall, Michigan (station ID 04103500).

4. Flood-Inundation map of the Kalamazoo River from Marshall to Battle Creek Michigan, for a flood with a 2-percent exceedance probability corresponding to a gage height of 7.96 feet and an altitude of 884.61 feet (NAVD88) at the U.S. Geological Survey streamgage at Marshall, Michigan (station ID 04103500).

5. Flood-Inundation map of the Kalamazoo River from Marshall to Battle Creek Michigan, for a flood with a 1-percent exceedance probability corresponding to a gage height of 8.30 feet and an altitude of 884.95 feet (NAVD88) at the U.S. Geological Survey streamgage at Marshall, Michigan (station ID 04103500).

6. Flood-Inundation map of the Kalamazoo River from Marshall to Battle Creek Michigan, for a flood with a 0.2-percent exceedance probability corresponding to a gage height of 9.11 feet and an altitude of 885.76 feet (NAVD88) at the U.S. Geological Survey streamgage at Marshall, Michigan (station ID 04103500). 


\title{
Flood-Inundation Maps for a 15-Mile Reach of the Kalamazoo River from Marshall to Battle Creek, Michigan
}

\author{
By Christopher J. Hoard, Kathleen K. Fowler, Moon H. Kim, Chad D. Menke, Scott E. Morlock, \\ Marie C. Peppler, Cynthia M. Rachol, and Matthew T. Whitehead
}

\section{Abstract}

Digital flood-inundation maps for a 15-mile reach of the Kalamazoo River from Marshall to Battle Creek, Michigan, were created by the U.S. Geological Survey (USGS) in cooperation with the U.S. Environmental Protection Agency to help guide remediation efforts following a crude-oil spill on July 25, 2010. The spill happened on Talmadge Creek, a tributary of the Kalamazoo River near Marshall, during a flood. The floodwaters transported the spilled oil down the Kalamazoo River and deposited oil in impoundments and on the surfaces of islands and flood plains. Six flood-inundation maps were constructed corresponding to the flood stage (884.09 feet) coincident with the oil spill on July 25, 2010, as well as for floods with annual exceedance probabilities of $0.2,1,2,4$, and 10 percent. Streamflow at the USGS streamgage at Marshall, Michigan (USGS site ID 04103500), was used to calculate the flood probabilities. From August 13 to 18, 2010, 35 channel cross sections, 17 bridges and 1 dam were surveyed. These data were used to construct a water-surface profile for the July 25,2010 , flood by use of a one-dimensional step-backwater model. The calibrated model was used to estimate watersurface profiles for other flood probabilities. The resulting six flood-inundation maps were created with a geographic information system by combining flood profiles with a 1.2foot vertical and 10-foot horizontal resolution digital elevation model derived from Light Detection and Ranging data.

\section{Introduction}

On July 26, 2010, Enbridge Energy Partners (LLC) reported to the U.S. Environmental Protection Agency (USEPA) and Michigan Department of Natural Resources and Environment (DNRE) that a pipeline had ruptured, spilling more than 800,000 gallons of crude oil into Talmadge Creek, a tributary of the Kalamazoo River near Marshall, Michigan (U.S. Environmental Protection Agency, 2010). Heavy rainfall during the 3 days preceding the spill in this same area exacerbated the spill by causing a flood with an approximate annual exceedance probability of 4 percent on the Kalamazoo River near Marshall (U.S. Geological Survey [USGS] streamgage station number 04103500). The elevated river deposited the spilled oil onto flood plains, and on top of submerged inchannel islands and intermixed it into soft bed sediments held behind three downstream dams: Ceresco, Monroe Street, and Morrow (fig. 1). The Morrow Dam pond is the largest and farthest downstream of the three impoundments.

In response to the spill, Federal, State, and local agencies mobilized cleanup and remediation crews and teams tasked with human health and wildlife protection. Initially, focus centered on air and water quality; after these immediate hazards had been evaluated and the area was deemed safe to access, attention shifted to characterizing the extent of the oil spill. The USGS was provided with a Pollution Removal Funding Authorization by the USEPA on August 11, 2010, and survey crews from the USGS were deployed August 13, 2010. These crews collected stream channel and bridge geometric data that were used to create a hydraulic model using the U.S. Army Corps of Engineers' Hydrologic Engineering Center River Analysis System (HEC-RAS), (U.S. Army Corps of Engineers, 2002a) from which flood-inundation maps were developed.

\section{Purpose and Scope}

The purpose of this report is to provide the USEPA with timely flood-inundation maps for a 15-mile stretch of the Kalamazoo River from Marshall to Battle Creek for assistance with remediation of flood-plain sediment and vegetation associated with an oil spill on July 25, 2010, on Talmadge Creek, a tributary to the Kalamazoo River near Marshall, Michigan. Six flood-inundation maps were constructed and include the July 25 flood and floods with exceedance probabilities of 0.2 , $1,2,4$, and 10 percent. These maps will help identify existing potential depositional areas as well as potential future depositional areas in the event that cleanup activities are not completed before another flood happens. The 15-mile reach mapped in this report corresponds to USEPA's Management Division $\mathrm{C}$, the reach immediately downstream from the confluence of Talmadge Creek and the Kalamazoo River. 

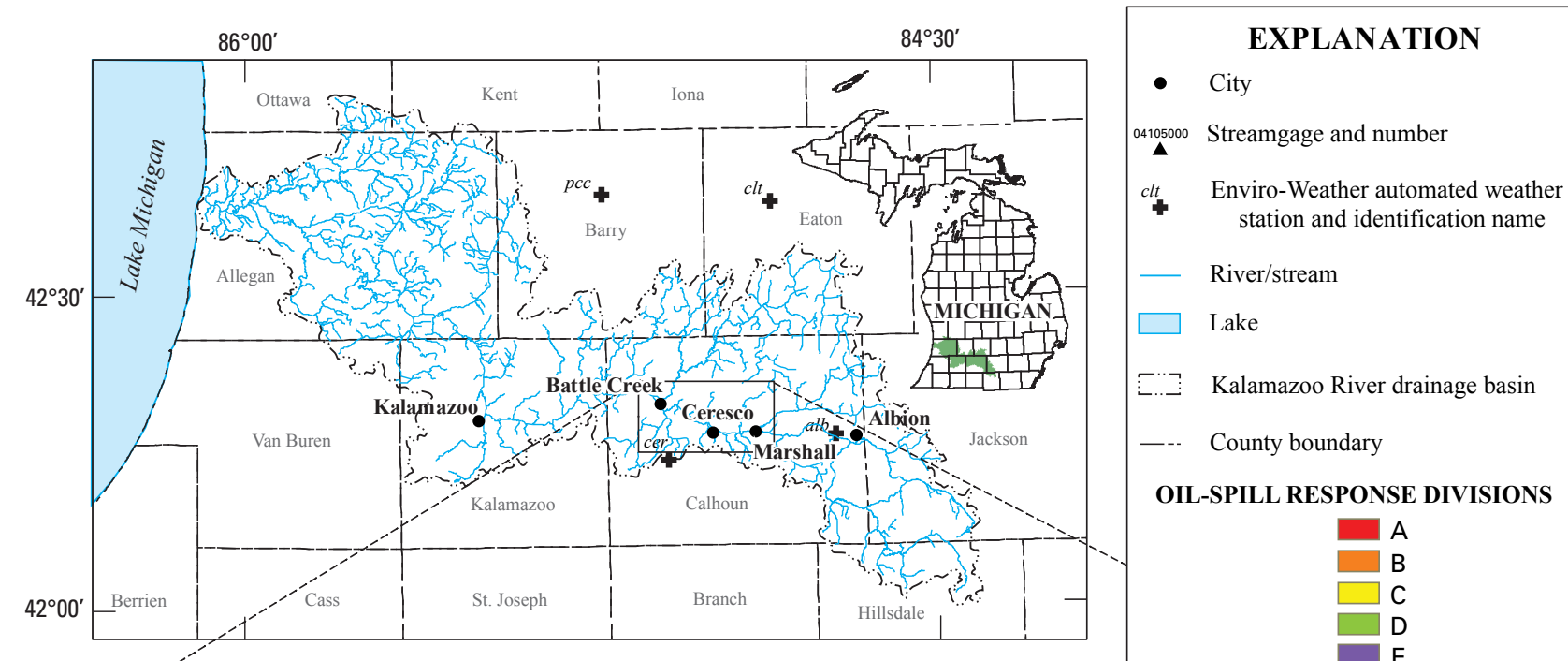

OIL-SPILL RESPONSE DIVISIONS
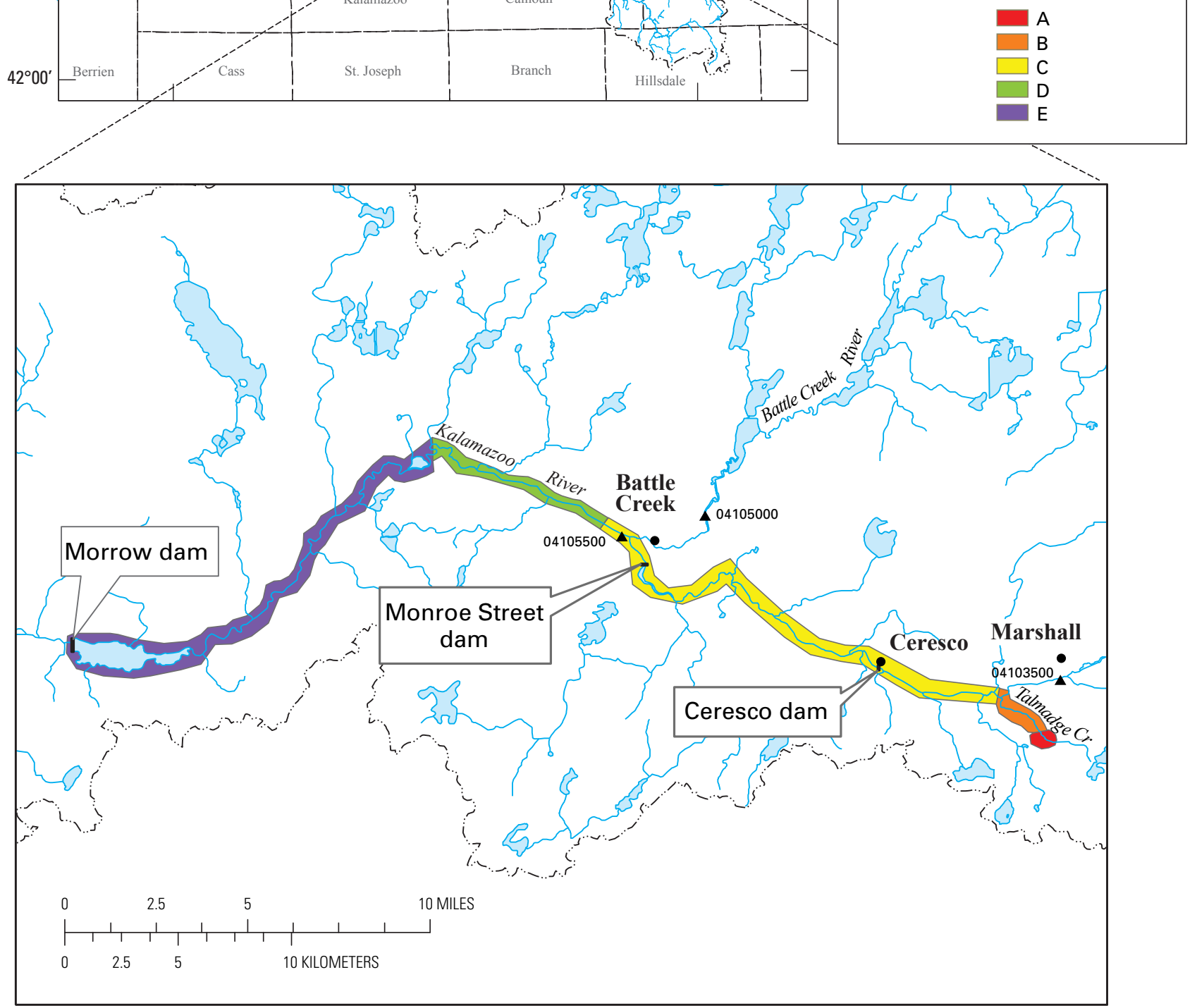

Projection: Lambert Conformal Conic

State Plane coordinate system, Michigan South, FIPS 2113

North American Datum of 1983 (NAD83)

City names and locations from U.S. Geological Survey digital raster graphics, Grand Rapids, Mich., 1:250,000 (42084-A1), and Racine, Mich., 1:250,000 (42086-A1). Hydrologic divides and hydrologic features from the U.S. Geological Survey National Hydrography Dataset (NHD, http://nhd.usgs.gov/, accessed 2010). County boundaries from Michigan Resource Information System.

Figure 1. Location of the Kalamazoo River and Enbridge oil-spill response divisions. 


\section{Study Area Description}

The Kalamazoo River is in southwest Michigan, has a drainage area of 2,020 $\mathrm{mi}^{2}$, and covers parts of 10 counties (Ottawa, Kent, Allegan, Barry, Eaton, Van Buren, Kalamazoo, Calhoun, Jackson, and Hillsdale; fig. 1). As part of the oil-spill response, affected areas of Talmadge Creek and the Kalamazoo River were sectioned into five management divisions within Calhoun and Kalamazoo Counties (fig. 1). All flood-inundation model scenarios are within Division C only. Divisions A, B, D and E were not modeled as a result of a combination of factors that include: a lack of hydraulic (stage and discharge) data for those divisions, and the inability to access areas where intense oil recovery efforts were taking place. Riparian areas along the Kalamazoo River in Division C are predominantly rural with mainly agriculture and residential properties adjacent to the river until the city of Battle Creek, which provides an urban setting for the remaining 2 miles of the Division.

\section{Antecedent Conditions}

The Kalamazoo River within the study reach received rain for 3 days prior the oil spill and the coincident flood. Precipitation was unevenly distributed throughout Calhoun

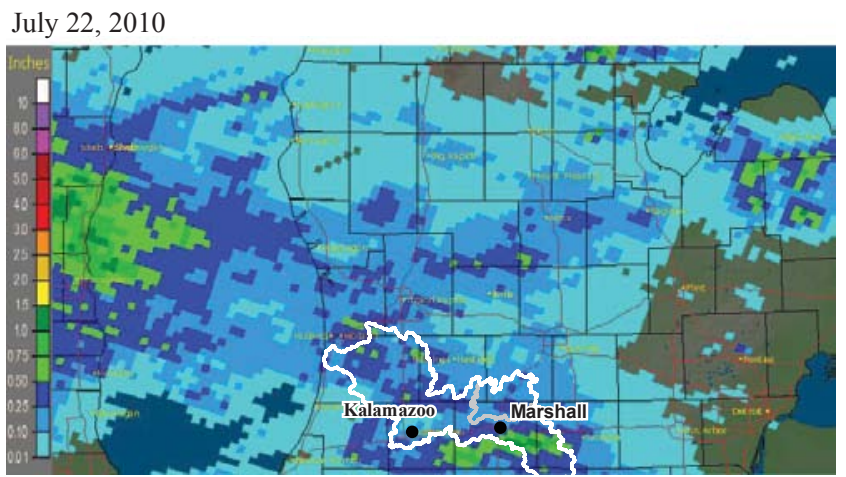

July 24, 2010

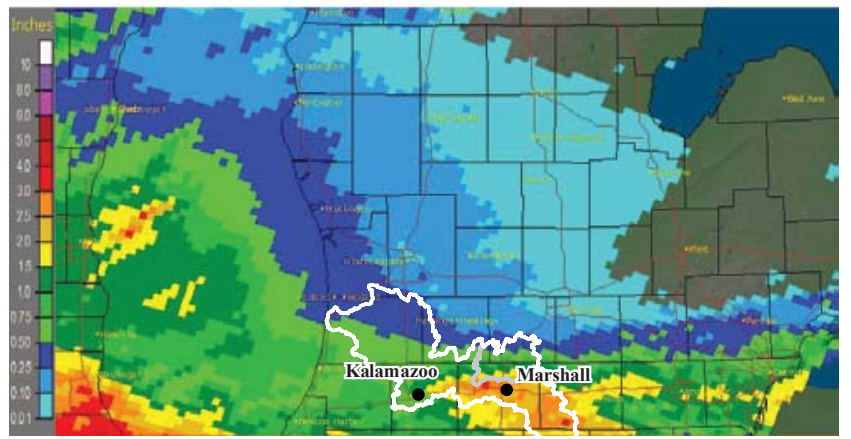

County and appeared to occur in very distinct bands that provided larger amounts of precipitation to the reach stretching from the city of Battle Creek to Albion (fig. 2). EnviroWeather stations (Michigan State University, 2010) in Ceresco and Albion recorded 5.70 and 5.65 inches of precipitation, respectively, from July 22 through midnight on July 25 . An Enviro-Weather station located to the north in Charlotte, near headwaters of the Battle Creek River and Hastings (not within the Kalamazoo River basin, though located within the same vicinity) recorded 0.62 inch and 0.87 inch, respectively, for the time period from July 22 to July 25 . The Enviro-Weather station at Ceresco recorded 5.70 inches of rain, with the most (3.40 inches) being recorded within a 1-hour period on the night of July 22, the evening of July 23, and the early morning of July 25. Precipitation recorded at the Albion station was less intense through the same timeframe.

The pattern of this storm is reflected in the USGS streamgage hydrographs for stations located on the Kalamazoo River at Marshall (station 04103500) and near Battle Creek (station 04105500), and on the Battle Creek River near Battle Creek (station 04105000) (fig. 3). Data from both of the Kalamazoo River streamgages documented the increase in streamflow in response to the precipitation received in the Ceresco to Albion part of the basin; data collected on the Battle Creek River showed that streamflow decreased during the same period.

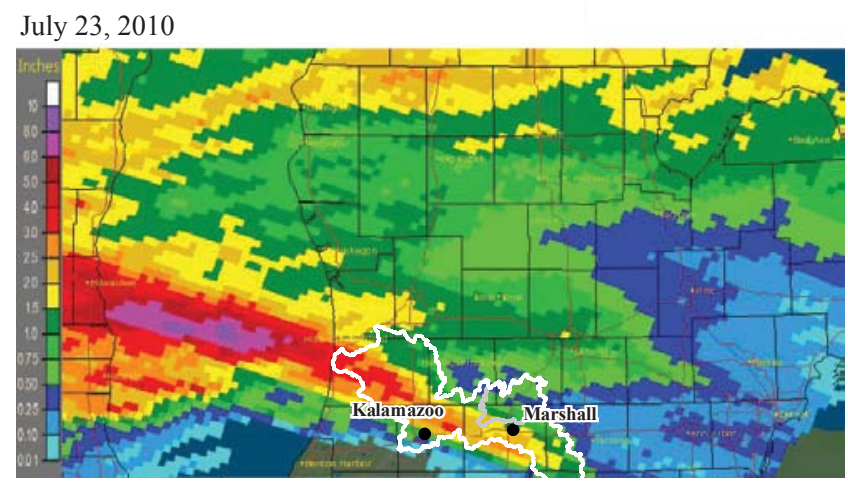

July 25, 2010

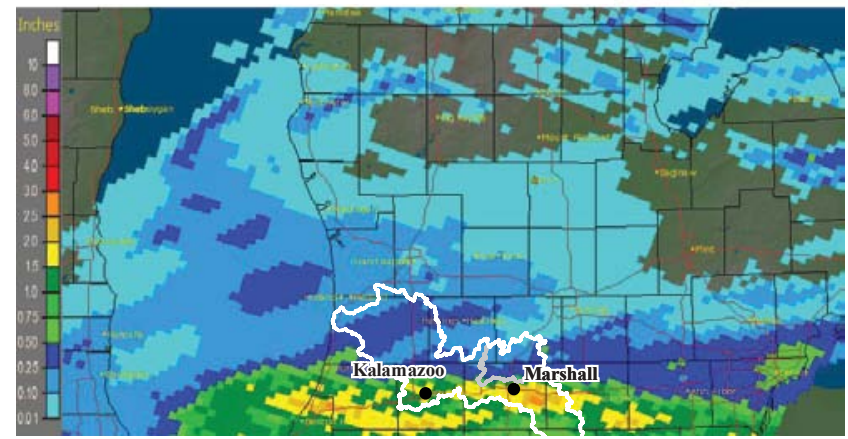

Figure 2. Illustration showing NEXRAD 1-day observed precipitation storm tracks from July 22 to July 25, 2010; NEXRAD data from National Weather Service data center located in Grand Rapids, Michigan. The colorbar is estimated precipitation in inches. 
Table 1. Precipitation, in inches, measured at Enviro-

Weather Automated Weather Network stations, July 22-25,

2010. (Michigan State University, 2010)

\begin{tabular}{lcccc}
\hline \multicolumn{1}{c}{ Date } & Ceresco & Albion & Charlotte & Hastings \\
\hline July 22, 2010 & 0.29 & 1.11 & 0.29 & 0.27 \\
July 23, 2010 & 3.40 & 2.60 & 0.09 & 0.10 \\
July 24, 2010 & 0.70 & 0.49 & 0.24 & 0.50 \\
July 25, 2010 & 1.31 & 1.45 & 0.00 & 0.0 \\
Total & 5.70 & 5.65 & 0.62 & 0.87 \\
\hline
\end{tabular}

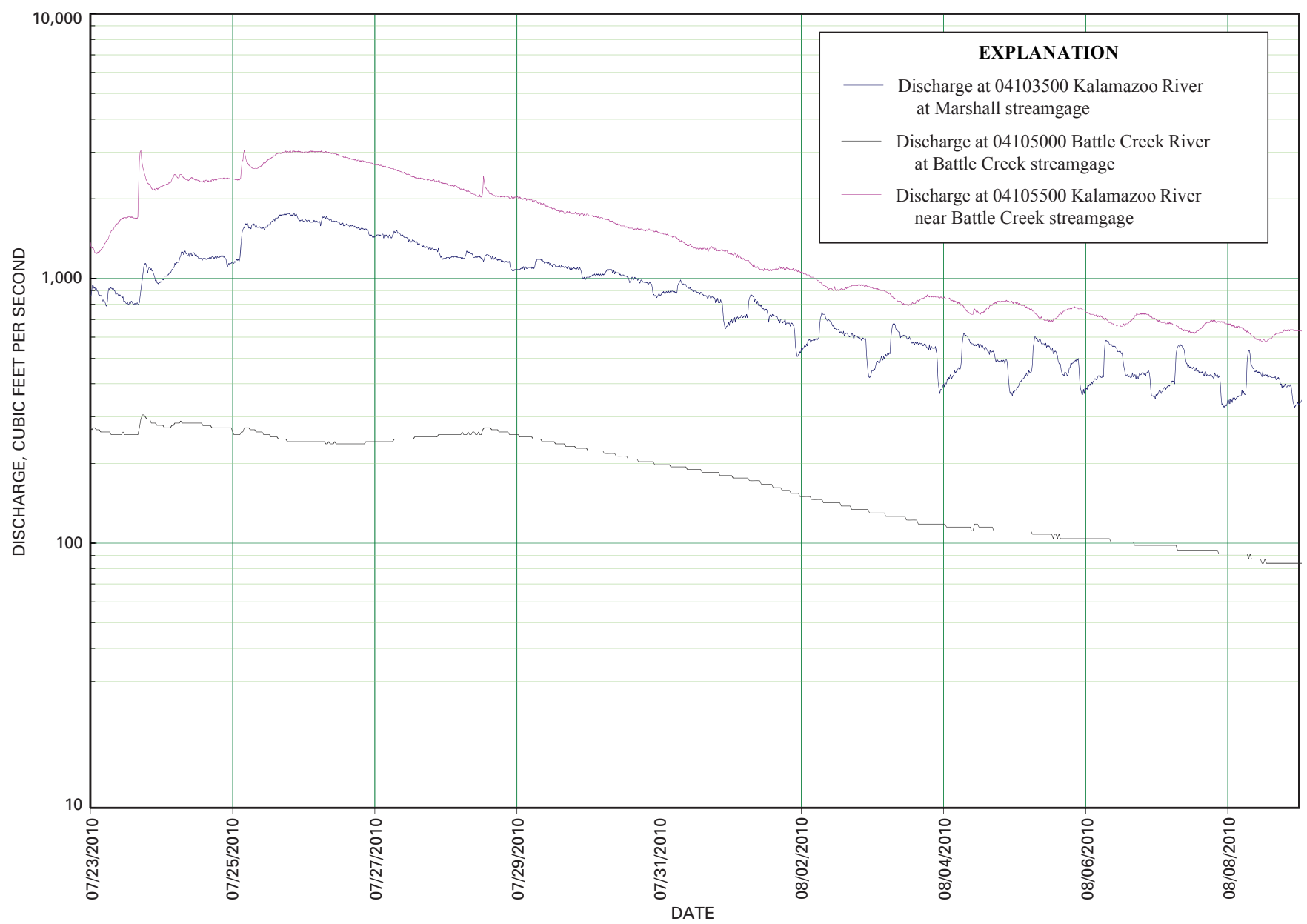

Figure 3. Discharge hydrographs for the Kalamazoo River near Marshall, Kalamazoo River near Battle Creek, and Battle Creek River at Battle Creek streamgages. 
With this storm pattern in mind, it is important to recognize that the flood-inundation maps should not be used for flood preparedness and response activities for precipitation events that affect the Battle Creek River portion of the Kalamazoo River basin. Secondary flood-inundation maps that reflect flooding within the Battle Creek River are beyond the scope of this study.

\section{Calculating Flood Probabilities}

A peak flow analysis was performed on both the Kalamazoo River at Marshall streamgage (04103500) and the Kalamazoo River at Battle Creek streamgage (04105500) to determine the $0.2,1,2,4$, and 10 percent probability of flow exceedance discharge values. Essentially, the peak flow data for the period of record for each gage were evaluated using statistical techniques described by the Hydrology Subcommittee of the Interagency Advisory Committee on Water Data (1981). The result of this analysis provides the probability of a certain discharge event occurring in any given year. For example, the 0.2-percent flow exceedance value for the Kalamazoo River at Marshall of $2,800 \mathrm{ft}^{3} / \mathrm{s}$ estimates that there is a 1 in 500 chance that a discharge of $2,800 \mathrm{ft}^{3} / \mathrm{s}$ will occur in a given year.

\section{Constructing Water-Surface Profiles}

The flood water-surface profiles used to produce the six flood-inundation maps were constructed by using (HEC-RA), version 4.1.0 (U.S. Army Corps of Engineers, 2002a). HECRAS is a one-dimensional step-backwater model for computing water-surface profiles with steady-state (gradually varied) or unsteady-state flow computation options. The HEC-RAS analysis was done with the steady-state flow computation option.

Channel cross sections were developed from USGS field surveys that were conducted in August 2010; these cross sections provide detailed channel elevation data below the water surface and were collected using hydroacoustic instrumentation to measure depth and Differential Global Positioning System (DGPS) instrumentation to determine horizontal position. Light Detection and Ranging (LiDAR) data with horizontal resolution of $10 \mathrm{ft}$ were used to provide digital elevation data for the portions of the cross sections that were above the water surface at the time of the surveys. The LiDAR data were collected in 2009 by the City of Battle Creek; post processing of these data was completed in the spring of 2010.

Various anthropogenic structures (bridges and dams) along the river affect or have the potential to affect flow in the river. To properly account for these structures in the model, their dimensions needed to be acquired. In total, 17 bridges were incorporated in the model. Bridge structures were measured and surveyed in the field concurrently with the river channel surveying. In addition, two dams were included in the model: the Ceresco dam in Ceresco and Monroe Street dam in Battle Creek. The Monroe Street dam was surveyed to determine its width and crest elevation. The Ceresco dam was not surveyed due to safety concerns; however, width and crest elevation data were provided by Wharry Engineering (Ralph Wharry, Wharry Engineering, written commun., 2010).

Water-surface profiles were first developed and calibrated to match a flow of $415 \mathrm{ft}^{3} / \mathrm{s}$ at the Kalamazoo River at Marshall streamgage. This flow was on the receding limb of the July 25 flood (fig. 3). Water-surface elevations were surveyed at 19 locations along the reach and used for calibration. The calibrated HEC-RAS model was then run for six streamflows corresponding to the July 25 event as well as for estimated floods with $0.2,1,2,4$, and 10 percent exceedance probabilities. These events correspond to streamflows at the Marshall streamgage of 1,700, 2,800, 2,280, 2,070, 1,860 , and $1,580 \mathrm{ft}^{3} / \mathrm{s}$, respectively and at the Battle Creek streamgage (04105500) of 3,040, 8,760, 6,820, 6,050, 5,300, and $4,350 \mathrm{ft}^{3} / \mathrm{s}$, respectively.

\section{Inundation Mapping}

Flood-inundation maps for the Division $\mathrm{C}$ reach were created in a geographic information system by combining floodwater-surface profiles and digital elevation model data. The digital elevation model data were derived from $10-\mathrm{ft}$ horizontal resolution LiDAR data with a vertical accuracy of $1.2 \mathrm{ft}$ obtained from the City of Battle Creek (Jonathon Merrick, City of Battle Creek, written commun., 2010). Estimated flood-inundation boundaries for each modeled profile were developed with HEC-GeoRAS software (U.S. Army Corps

Table 2. Gage height, water-surface altitude, and discharge associated with the July 25, 2010, and the 0.2, 1, 2, 4, and 10-percent flood exceedance events for the Kalamazoo River at Marshall (station 4103500).

\begin{tabular}{|c|c|c|c|c|c|c|}
\hline $\begin{array}{c}\text { Gage } \\
04103500\end{array}$ & $\begin{array}{c}\text { July } 25 \\
2010 \text { event }\end{array}$ & $\begin{array}{l}\text { 0.2-percent } \\
\text { exceedance }\end{array}$ & $\begin{array}{c}\text { 1-percent } \\
\text { exceedance }\end{array}$ & $\begin{array}{c}\text { 2-percent } \\
\text { exceedance }\end{array}$ & $\begin{array}{c}\text { 4-percent } \\
\text { exceedance }\end{array}$ & $\begin{array}{c}\text { 10-percent } \\
\text { exceedance }\end{array}$ \\
\hline Gage height (ft) & 7.44 & 9.11 & 8.30 & 7.96 & 7.60 & 7.10 \\
\hline Altitude (ft) & 884.09 & 885.76 & 884.95 & 884.61 & 884.25 & 883.75 \\
\hline Discharge $\left(\mathrm{ft}^{3} / \mathrm{s}\right)$ & 1,770 & 2,800 & 2,280 & 2,070 & 1,860 & 1,580 \\
\hline
\end{tabular}


of Engineers, 2002b). HEC-GeoRAS is a set of procedures, tools, and utilities for processing geospatial data in ArcGIS by using a graphical user interface (Whitehead and Ostheimer, 2009). The interface allows the preparation of geometric data for import into HEC-RAS and processes simulation results exported from HEC-RAS (U.S. Army Corps of Engineers, 2002b). USGS personnel then modified the HEC-GeoRAS results to ensure a logical transition of the boundary between modeled cross sections relative to the contour data for the land surface (Whitehead and Ostheimer, 2009). The resulting inundation maps have a vertical accuracy of about $1.2 \mathrm{ft}$.

\section{Summary}

The USGS produced six flood-inundation maps to help guide remediation of flood-plain sediment and vegetation following a large crude oil spill that affected the Kalamazoo River between Marshall and Battle Creek, Michigan. These flood-inundation maps correspond to a flood that occurred on July 25,2010 , as well floods with exceedance probabilities of $0.2,1,2,4$, and 10 percent. The flood associated with the spill had an annual exceedance probability of approximately 4 percent. High-resolution digital elevation model data were combined with surveyed river channel elevations to construct flood profiles along a 15-mile reach known as Division C.

This model was calibrated to conditions at the time of the river channel survey and then used to generate water-surface profiles associated with the five flood probabilities that bracketed the size of the July 25 flood. The simulated water-surface profiles were combined with high-definition digital topographic data to produce flood-inundation maps with a vertical accuracy of $1.2 \mathrm{ft}$ (Jonathon Merrick, City of Battle Creek, written commun., 2010).

\section{Acknowledgments}

The authors thank the USGS field survey crews from Michigan, Ohio, Kentucky, and Indiana who responded quickly to collect river channel, bridge, and dam geometry data. The authors would also like to thank Rodney Southard and Faith Fitzpatrick from the USGS for detailed and thorough technical reviews of the report.

\section{References Cited}

Hydrology Subcommittee of the Interagency Advisory Committee on Water Data, 1981, Guidelines for determining flood frequency: Reston, Va., U.S. Geological Survey Bulletin 17B, Office of Water Data Collection, 183 p.

Michigan State University, 2010, Enviro-Weather Automated Weather Station Network, Climate Database accessed August 30, 2010 at http://www.agweather.geo.msu.edu/ mawn/.

U.S. Army Corps of Engineers, Hydrologic Engineering Center, 2002a, HEC-RAS River Analysis System, hydraulic reference manual, version 3.1, [variously paged].

U.S. Army Corps of Engineers, Hydrologic Engineering Center, 2002b, HEC-GeoRAS, accessed on November 27, 2007, at URL http://www.hec.usace.army.mil/software/ hec-ras/hec-georas.html.

U.S. Environmental Protection Agency, 2010, EPA response to Enbridge spill in Michigan, accessed on August 20, 2010 at http://www.epa.gov/enbridgespill/.

Whitehead, M.T., and Ostheimer, C.J., 2009, Development of a flood-warning system and flood-inundation mapping for the Blanchard River in Findlay, Ohio: U.S. Geological Survey Scientific Investigations Report 2008-5234, 9 p. 
For more information concerning this publication, please contact:

Director, Michigan Water Science Center

U.S. Geological Survey

6520 Mercantile Way, Suite 5

Lansing, MI 48911

(517) 887-8903

Or visit the Michigan Water Science Center Web site at: http://mi.water.usgs.gov/ 